\title{
ОСОБЛИВОСТІ РЕМОДЕЛЮВАННЯ ЗВИВИСТИХ АРТЕРІЙ ЕНДОМЕТРІЯ ПРИ ФОРМУВАННІ СУДИННОГО КОМПОНЕНТА ФІБРОВАСКУЛЯРНОГО ЯДРА ПОЛІПІВ У ЖІНОК РЕПРОДУКТИВНОГО ВІКУ
}

\section{ДВНз «Тернопільський державний медичний університет імені І. Я. Горбачевського мОз України»}

РЕзЮМЕ. Питанням ремоделювання ендометрія та його складових в останні роки приділяється все більше уваги. Функціональний шар матки має унікальну властивість - фізіологічний ангіогенез, який залежить від гормональної циклічності жіночого організму. Зміни ендометрія загалом та його судинного компонента зокрема вивчені не достатньо. Потребує уваги питання ремоделювання звивистих артерій функціонального шару матки за умов впливу додаткових зовнішніх факторів.

Мета - на основі патоморфологічного аналізу архівних препаратів ендометрія жінок репродуктивного віку із застосуванням додаткових гістохімічних методик визначити структурні особливості судинного компонента та фіброваскулярного ядра поліпів ендометрія.

Матеріал і методи. Досліджували 55 біопсійних архівних препаратів ендометрія жінок репродуктивного віку: 43 препарати поліпів ендометрія, 12 - фізіологічного ендометрія. Проводили стандартне фарбування гематоксиліном та еозином, а також використовували додаткові гістохімічні методи фарбування: резорцинфуксином за Хартом, пікрофусцином за Ван Гізон та трихромним методом Масона.

Результати. Серед 43 випадків поліпів ендометрія виявлено 15 випадків залозистих поліпів, 26 - залозистостромальних. Клінічно у 33 пацієнток діагностовано непліддя, 10 жінок були фертильними. Для контролю відібрали 12 зразків нормального функціонального ендометрія: по 6 випадків у фазах проліферації та секреції.

Гістохімічні методи забарвлення дозволили визначити особливості будови фіброваскулярного ядра поліпів ендометрія - наявність осередків великих товстостінних судин, які часто розташовуються ланцюжками у вигляді «доріжки». Встановлено, що до складу ендометріальної залози в нормі входять клітини епітелію та циркулярно розташовані навколо них волокнисті елементи сполучної тканини, які візуалізуються при використанні додаткових гістохімічних фарбувань. Наші дослідження показали, що у нормі в спіральних артеріях волокнисті елементи відсутні, а за умов ремоделювання ендометрія у вигляді його поліпозної трансформації волокнисті елементи $\epsilon$ обов'язковим елементом артерій. Додаткові зовнішні фактори (такі, як хронічне запалення тощо) сприяють прогресуючій васкуляризації поліпів. Остання проявляється не лише сформованим фіброваскулярним ядром поліпа, а й феноменом капіляризації поліпів.

Висновки. Наявність фіброваскулярного ядра в поліпах ендометрія $\epsilon$ проявом судинного ремоделювання, яке полягає в появі сформованих артерій із еластично-колагеновим каркасом. Скупчення судин характерні для фіброваскулярної ніжки поліпа і, разом з більш вираженим волокнистим характером строми, можуть бути цінною диференційно-діагностичною ознакою, що відрізняє поліп від фонової тканини ендометрія при його невеликих розмірах. Описана васкуляризація є вирішальною для прогресуючого росту поліпа та його можливої малігнізації. Застосування додаткових гістохімічних методів дозволяє полегшити диференційну діагностику поліпа як від різних видів гіперплазій, так і від нормального ендометрія.

КЛючОВІ СлОВА: ремоделювання ендометрія; ангіогенез; поліп ендометрія; фіброваскулярне ядро поліпа; звивисті артерії; репродуктивний вік.

Вступ. Протягом останніх років проводиться все більше досліджень, присвячених вивченню внутрішньоматкових патологій, до яких належать поліпи ендометрія, та механізмів їх виникнення [1-3]. Розміри, розташування та гістологічна структура поліпозних трансформацій функціонального шару матки є варіабельними і мають залежність від багатьох факторів [13]. Наслідки патологічної трансформації ендометрія можуть бути різноманітні. Серед них: дисменореї з кровотратами та анеміями, злоякісні новоутворення і порушення фертильності [4-6]. Думки вчених з приводу залежності непліддя від розмірів внутрішньоматкової патології суперечливі. Існує думка, що виникненню порушень фертильності сприяють будь-які внутрішньоматкові новоутворення, або $ж$, що причиною можуть бути лише поліпи великих розмірів, активний ріст яких перешкоджає як настанню вагітності, так і успішній імплантації заплідненої яйцеклітини в порожнині матки.

Будь-яке новоутворення тканини, яке перевищує за своїм об'ємом 1,0-2,0 мм³ , потребує підвищеного насичення киснем, що зумовлює гіпоксію прилеглих тканин, яка, в свою чергу, стимулює ангіогенез, оскільки метаболічні потреби перевищують перфузійну здатність існуючих судин [5, $10,15]$. $Є$ також думка, що провідну роль у зміні особливостей мікросудинного русла відіграє тривалість пухлинного процесу, а не обсяг пухлини [10]. Активний ріст новоутворень сприяє посиле- 
Огляди літератури, оригінальні дослідження, погляд на проблему, ювілеї

ній проліферації судинних комплексів та неоангіогенезу. Самі судини є дезорганізованими: пухкі, не вистелені шаром епітеліальних клітин, що призводить до їх аномально високої проникності та кровоточивості [15]. Ангіогенез - процес багатоступеневий, включає активацію та проліферацію клітин ендотелію, деградацію їх базальної мембрани, міграцію через екстрацелюлярний матрикс із проліферацією гладком'язових клітин з наступним формуванням судин $[7,15]$.

Відомо, що ангіогенез для непошкоджених тканин не характерний. Активізація його відбувається за умов патологічного росту тканин при пухлинах, гострих чи хронічних запальних процесах тощо. Ендометрій вважають унікальним винятком із цього правила, оскільки циклічні зміни, що відбуваються у ньому, сприяють постійному ангіогенезу [11].

Стан кровотоку в маткових артеріях та процеси ангіогенезу в ендометрії вивчені недостатньо [9]. Здебільшого це питання розглядають з погляду ультрасонографії чи імуногістохімії. Перший варіант не $\epsilon$ високоінформативним, його можна застосовувати лише для попередньої діагностики, а другий - потребує часу та значних матеріальних затрат. Незважаючи на певний науковий прогрес у галузі репродуктивної медицини та досліджень стану ендометрія жінки, питання трансформації структурних компонентів слизової оболонки матки у нормі та при внутрішньоматкових утворах вивчене недостатньо. Особливого нового підходу вимагає питання трансформації ендометрія при формуванні власне судинної ніжки поліпа ендометрія у жінок репродуктивного віку та морфологічної діагностики даного ремоделювання ендометрія на ранніх етапах.

Мета - на основі патоморфологічного аналізу архівних препаратів ендометрія жінок репродуктивного віку визначити структурні особливості судинного компонента та фіброваскулярного ядра поліпів ендометрія із застосуванням додаткових гістохімічних методик.

Матеріал і методи дослідження. Досліджували 55 біопсійних архівних препаратів ендометрія жінок репродуктивного віку: 43 поліпи ендометрія, 12 - фізіологічного ендометрія. Проводили стандартне фарбування гематоксиліном та еозином і додаткові гістохімічні методи: фарбування резорцин-фуксином за Хартом, пікрофусцином за Ван Гізон та трихромним методом Масона.

Результати гістоморфологічних досліджень опрацьовували та реєстрували цифровим фотоапаратом мікроскопа Mеiji 4300 LED, об'єктив ×40, фотоапаратом Canon 550D з перехідником MA150/50 та адаптером МА986 із збільшенням ×1.9. Математичну обробку даних проводили з використанням методів варіаційної статистики, точного критерію Фішера і критерію Манна-Уїтні. Варіант похибки становив р>0,05.

Результати й обговорення. Серед 43 випадків поліпів ендометрія виявлено 15 випадків залозистих поліпів, 26 - залозисто-стромальних. Клінічно у 33 пацієнток діагностовано непліддя, 10 жінок були фертильні. Для контролю відібрали 12 зразків нормального функціонального ендометрія: по шість зразків у фазах проліферації та секреції.

Структура залозистих поліпів ендометрія характеризувалася порушенням стромально-залозистого балансу: переважав залозистий компонент, розташування залоз було нерівномірним, різної форми та розмірів, траплялися кістозно-розширені залози. Залози були розташовані щільно, форма їх - химерною, нерідко розгалуженою. Епітелій залоз - високий, призматичний, переважно багаторядний із різко базофільними клітинами та значною кількістю мітозів. Поряд із активно мітотичними клітинами із темним ядром спостерігали вогнища з великих епітеліальних клітин із блідою еозинофільною дрібнозернистою цитоплазмою. У залозах із кістозною трансформацією траплялися вогнища сплощеного епітелію за типом низького призматичного. Строма аденоматозних поліпів зазвичай відповідала стромальній тканині поліпів базального типу, але частіше спостерігали її виражений фіброз, а також гіперхромію аргірофільного каркасу (рис. 1).

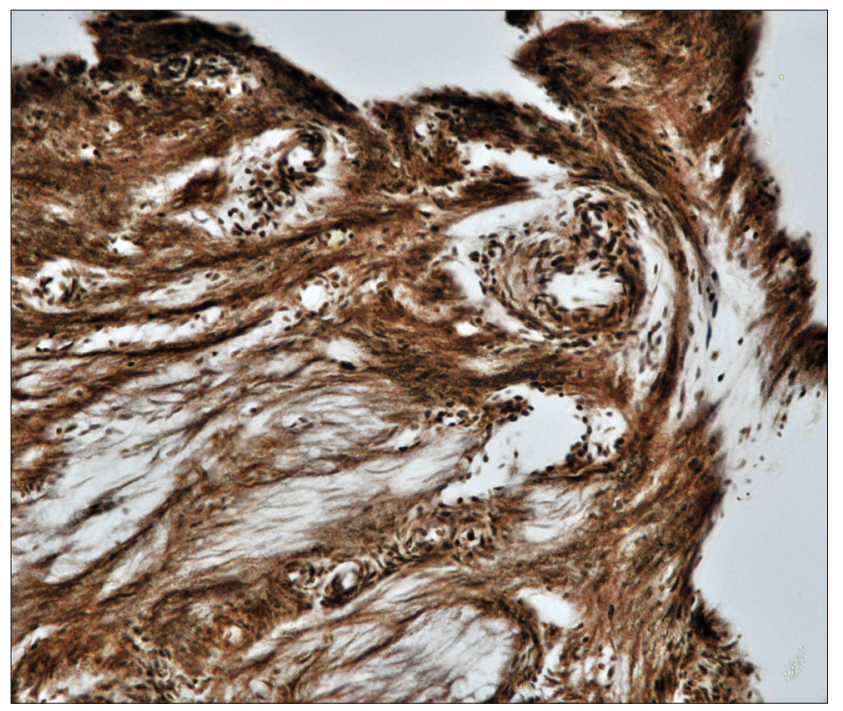

Рис. 1. Залозистий поліп ендометрія: сітка аргірофільних волокон в стромі та в складі фіброваскулярного ядра поліпа. Забарвлення - реакція сріблення. 36. $\times 200$.

Строми було мало, переважно в складі “судинної ніжки", яку представляли від трьох до п'яти товстостінних судин (рис. 2). 
Огляди літератури, оригінальні дослідження, погляд на проблему, ювілеї

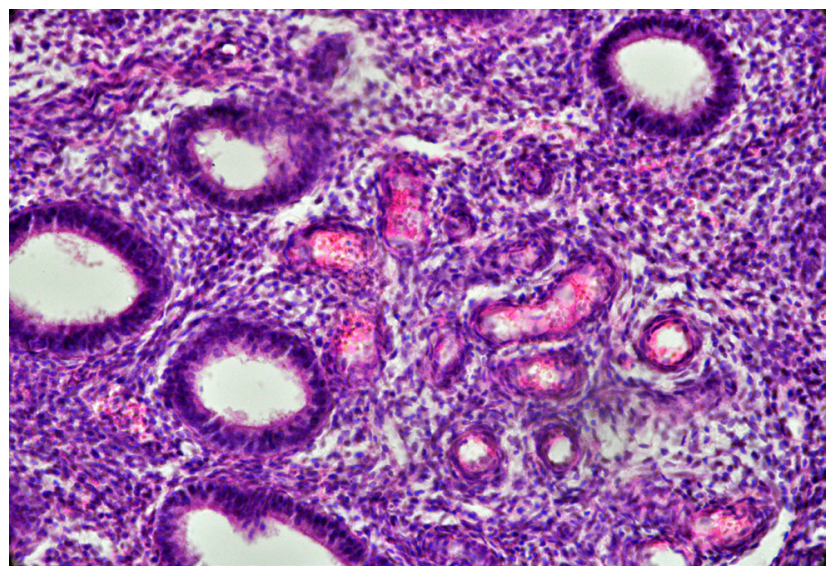

Рис. 2. Залозистий поліп: товстостінні судини базального шару ендометрія, залучені в ніжку поліпа. Забарвлення гематоксиліном та еозином. 36. ×200.

Залозисто-фіброзні поліпи були представлені поліпозними утворами із переважанням залозистого та стромального компонентів. Поділ на шари відсутній, велика кількість залоз різної форми та розмірів, гландулярний епітелій низький призматичний, проліферативного типу, із різко базофільними клітинами. Фіброваскулярне ядро представлене п'ятьма і більше товстостінними судинами, які місцями галузилися. Лімфоцитарна інфільтрація стромального компонента наявна в усіх випадках: вогнищева - в 25 \% , дифузна - у $15 \%$. Поліпи із переважанням залозистого компонента характеризувалися дифузною кістозною трансформацією залозистих елементів. Епітелій залоз - високий, призматичний, у залозах із кістозною трансформацією траплялося сплощення епітелію, що нагадував низький призматичний. Цитоплазма клітин заповнена слизом, наявні глікопротеїни. Виявляли вогнищеву лімфоцитарну інфільтрацію строми у вигляді лімфоїдних фолікулів. Строми було мало, переважно в складі "судинної ніжки". Остання включає судинний компонент - від трьох до п'яти товстостінних судин та фіброзний компонент - дрібноволокнисту сполучнотканинну сітку. Це так зване фіброваскулярне ядро поліпа. Фіброзний компонент формував щільну сітку-каркас, між сполучнотканинними волокнами якої визначалися тонкопетлисті аргірофільні волокна. Судини фіброваскулярного ядра із дифузним склерозом та гіалінозом. У судинній стінці гістохімічно спостерігається переважання фібротизованих колагенових волокон. Крім того, визначаються еластичні волокна по всьому периметру судини. Еластичні волокна дистрофічно змінені-з вогнищевим гіпереластозом та гіперхромією, місцями із ознаками фрагментації та мультиплікації (рис. 3).

У поліпах із переважанням стромального компонента спостерігалася значна кількість фібро-

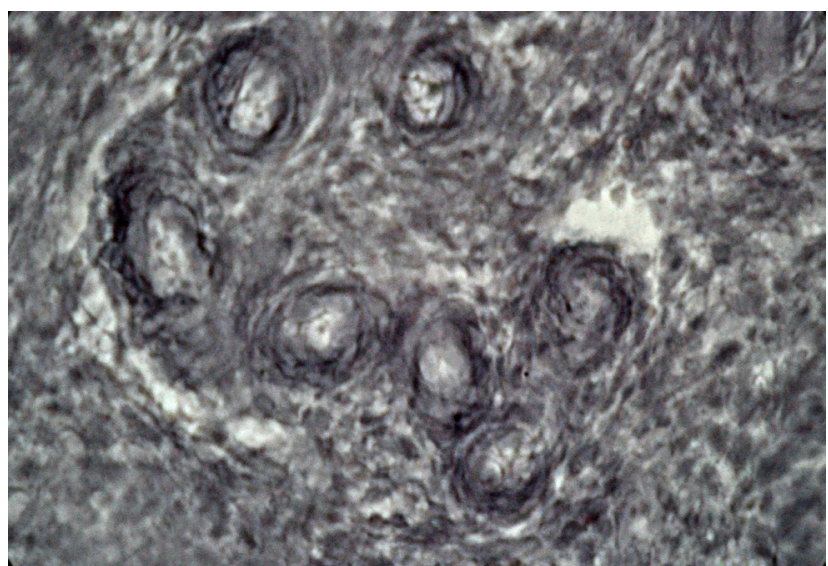

Рис. 3. Судини фіброваскулярного ядра поліпа ендометрія. Дистрофічні зміни еластичних волокон по всьому периметру судини. Забарвлення пікрофуксином за Хартом. 36. ×400.

тизованої сполучної тканини, залозистих елементів було мало, переважно на етапах інволютивних та атрофічних змін. Строма щільна, волокниста, морфологічно переважають сполучнотканинні елементи, місцями наявні тонкі аргірофільні волокна. Судинний пучок виглядав як клубки судин із потовщеними стінками. У структурі фіброваскулярного ядра наявна виражена сітка-каркас навколо товстостінних судин. Навколо дрібних поверхневих судин та залозистих компонентів виявлено сполучнотканинні волокна, що переплітаються у вигляді дрібноволокнистої сітки. Структурні волокнисті компоненти потовщуються та щільніше розташовуються у напрямку фіброваскулярного ядра. Зустрічаються вогнища густої сітки колагенових волокон, що оточують кістозно-розширені, зі стоншеними стінками залози, епітеліальний компонент яких представлений сплощеними клітинами.

Фіброзні поліпи представлені фіброзною сполучною тканиною та поодинокими судинами із вираженим периваскулярним фіброзом (рис. 4).

Залози в таких поліпах - поодинокі, атрофічні. Вважаємо, що відсутність слизу та глікопротеїнів може бути ознакою гіпоестрогенії. Строма представлена грубою сполучною тканиною, незрілі аргірофільні волокна відсутні. Такі поліпи ми спостерігали у двох жінок пізнього репродуктивного віку із вторинним непліддям. Поряд із цим відомий той факт, що фіброзні поліпи можуть бути проявом дисгормонозів молодих жінок.

Крім добре вираженого фіброваскулярного ядра, в структурі залозистих та залозисто-фіброзних поліпів спостерігалася капіляризація строми. Тонкостінні капіляри розташовувалися у стромі поліпів у безпосередній близькості від фіброваскулярного ядра. Вони утворювали галузисті структури, що пронизували строму поліпа на різних рівнях. 


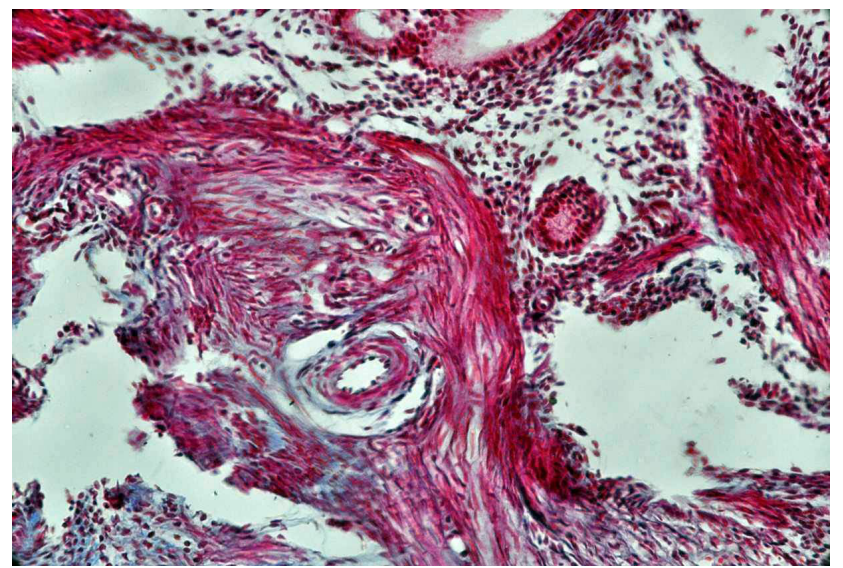

Рис. 4. Фіброзний поліп ендометрія. Товстостінна судина із вираженим периваскулярним фіброзом. Забарвлення трихромним методом Масона. 36. ×200.

Капіляризація поліпів практично не визначалася при рутинному забарвленні гематоксилінеозином, але достатньо чітко спостерігалася при використанні додаткових методик - фарбуванні на еластичні та колагенові волокна (рис. 5).

Цей феномен виникає як наслідок хронічного ендометриту в поєднанні із гормональним впливом. Про це свідчить наявність дрібновогнищевих лімфоцитарних інфільтратів, що розташовуються навколо капілярів. Капіляризація, як прояв ангіогенезу пухлинних утворів, забезпечує адекватний кровотік та сприяє подальшому пухлинному росту. В той же час не виключається гормональний ґенез розвитку поліпів - так звані функціонуючі поліпи. Відомо, що у нормі підвищення концентрації естрадіолу пов'язане із швидким ростом ендотелію судин строми ендометрія під час проліферативної фази менструального циклу [6]. В секреторну фазу під впливом прогестерону відбуваються диференціювання субепітеліальної капілярної сітки, ріст та спіралізація артеріол. Адекватна модуляція ангіогенезу забезпечує успішну інвазію трофобласта, ремоделювання спіральних артерій та формування матково-плацентарних судин $[12,14]$. Цей же принцип гормональної регуляції, мабуть, має місце й при формуванні поліпа ендометрія. Вивчення прогестеронової та естрогенової рецепції у зразках ендометрія на даному етапі дослідження ми не проводили. Одним із проявів можливої гормональної регуляції в наших дослідженнях була наявність нерівномірно розташованих альціанпозитивних слизистих мас у частині гландулярного епітелію та поза ним (рис. 6), а також скупчення глікопротеїнів.

Переважно такі зміни ми виявляли в залозистих та залозисто-фіброзних поліпах із переважанням залозистого компонента. Слід зазначити, що

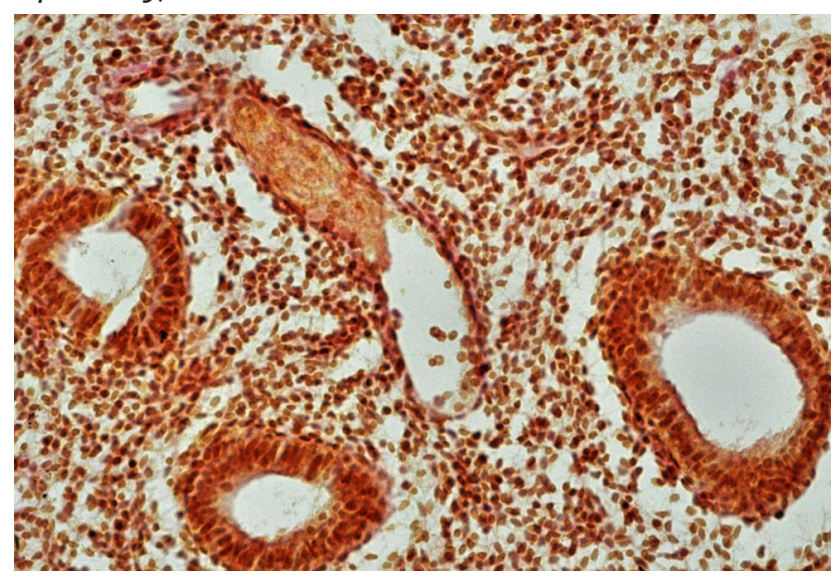

Рис. 5. Залозисто-стромальний поліп ендометрія. Еритростаз у тонкостінному капілярі стромального компонента. Забарвлення за Ван Гізон. 36. ×400.

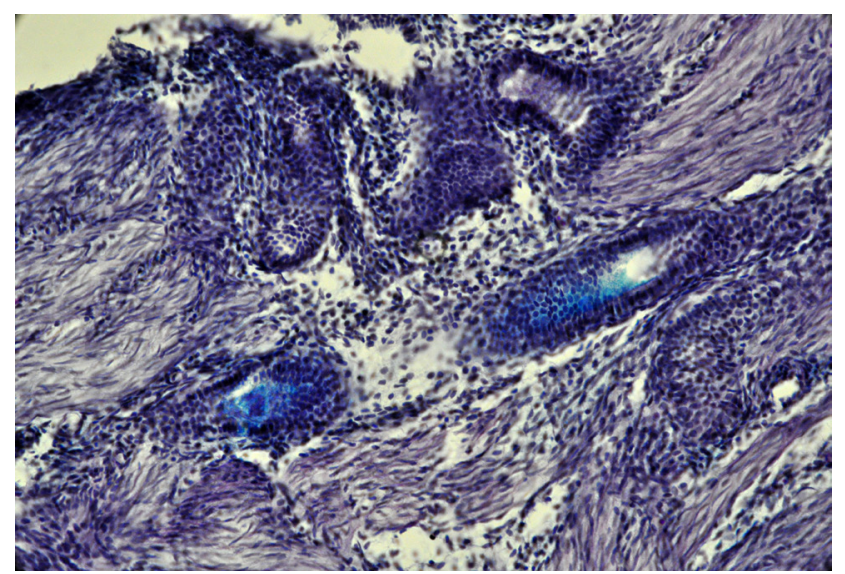

Рис. 6. Альціанпозитивні слизисті елементи у просвітах залозистих структур поліпа ендометрія. Забарвлення альціановим синім. 36. ×400.

такі поліпи переважали у жінок репродуктивного віку (30-40 років) та спостерігалися як при первинному, так і при вторинному безплідді.

Висновки. 1. Наявність фіброваскулярного ядра в поліпах - це прояв судинного ремоделювання, яке полягає в появі сформованих артерій із еластично-колагеновим каркасом.

2. До складу ендометріальної залози в нормі входять клітини епітелію та циркулярно розташовані навколо них волокнисті елементи сполучної тканини, які візуалізуються при використанні додаткових гістохімічних пофарбувань.

3. Встановлено, що у спіральних артеріях в нормі відсутні волокнисті елементи, а за умов модифікації ендометрія у вигляді поліпозної його трансформації- волокнисті елементи наявні.

4. Скупчення судин надзвичайно характерні для фіброваскулярної ніжки поліпа і, разом з більш вираженим волокнистим характером строми, можуть служити цінною диференційно-діагностичною ознакою, що відрізняє поліп від фонової тка- 
Огляди літератури, оригінальні дослідження, погляд на проблему, ювілеї

нини ендометрія при дуже невеликих розмірах поліпа.

5. Хронічне запалення, в поєднанні із іншими факторами, сприяє прогресуючій васкуляризації поліпів. Вона проявляється не лише сформованим фіброваскулярним ядром поліпа, а й феноменом капіляризації поліпів. Описана васкуляризація $\epsilon$ вирішальною для прогресуючого росту поліпа та його можливої малігнізації.

6. Фіброваскулярне ядро $\epsilon$ патогномонічною гістологічною ознакою поліпів, тому застосування додаткових гістохімічних методів (трихромний метод Масона, фарбування пікрофусцином за Ван Гізон, резорцин-фуксином за Хартом) дозволяє полегшити диференційну діагностику поліпа від різних видів гіперплазій та нормального ендометрія.

Перспективи подальших досліджень. Потребують подальшого вивчення особливості ремоделювання ендометрія за умов впливу зовнішніх та внутрішніх факторів та моделюючий вплив ангіогенезу на структуру судинного компонента функціонального шару матки.

\section{ЛІТЕРАТУРА}

1. The pathogenesis of endometrial polyps: a systematic semi-quantitative reviev / U. Indraccolo, R. Di Iorio, M. Matteo [et al.] // European Journal of Gynaecological Oncology. - 2013. - Vol XXXIV, No. 1. - P. 5-22.

2. Клынишкова Т. В. Клиническое значение комплексной оценки рецепторного статуса эндометрия при эндометриальных полипах/Т. В. Клынишкова, Н. Б. Фролова, С. И. Мозговой // Акушерство и гинекология. 2011. - № 3. - С. 37-41.

3. Козырева Е. В. Роль факторов роста в патогенезе бесплодия и невынашивания беременности / Е. В. Козырева, Л. Ю. Давидян // Современные проблемы науки и образования. - 2015. - № 4.

4. Кузик Ю. І. Гіперпластичні процеси ендометрія у жінок із безплідністю: зіставлення результатів ультрасонографічних та патоморфологічних досліджень ендометрія / Ю. І. Кузик, Г. М. Чорненька // Здоровье женщины. - 2018. - № 7 (133). - С. 129-133.

5. Захарова Н. Б. Диагностическое значение исследования фактора роста эндотелия сосудов в сыворотке крови / Н. Б. Захарова, Д. А. Дурнов, В. Ю. Михайлов // Фундаментальные исследования. - 2011. - № 11. - С. 215-220.

6. Hannan N. J. Analysis of fertility-related soluble mediators in human uterine fluid identifies VEGF as a key regulator of embryo implantation / N. J. Hannan, P. Paiva, K. L. Meehan // Endocrinology. - 2011. - Vol. 152. - P. 4948-4956.

7. Carmeliet P. Angiogenesis in health and disease / P. Carmeliet // Nat. Med. -2003. - Vol. 9. - P. 653-660.

8. Бурлев В. А. Циклический ангиогенез эутопического эндометрия / В. А. Бурлев, Н. А. Ильясова,
О. А. Шишканова // Проблемы репродукции. - 2006. № 6. - С. 22-30.

9. Молекулярные механизмы ангиогенеза в физиологических и патологических процессах / С. В. Луценко, С. М. Киселев, Н. Б. Фельдман [и др.] // Введение в молекулярную медицину ; под. ред. Пальцева М. А. - М. : ОАО “Медицина”, 2004. - С. 446-496.

10. Дубина М. В. Влияние дексаметазона на функциональные свойства микрососудов у крыс с лимфосаркомой Плисса / М. В. Дубина // Вопр. онкологии. 1999. - № 45. - С. 655-659.

11. Excessive angiogenesis: a new theory for endometriosis / J. Tsaltas, P. A. Rogers, V. C. Gargett, D. L. Healy // Current Obst. Gynaec. - 1998. - Vol. 8. - P. 186-188.

12. Binder N. K. Endometrial signals improve embryo outcome: functional role of vascular endothelial growth factor isoforms on embryo development and implantation in mice / N. K.Binder, J. Evans, D. K. Gardner // Hum. Reprod. - 2014. - Vol. 29, No. 10. - P. 2278-2286.

13. Чорненька Г. М. Поліпозна трансформація ендометрія: особливості діагностики в жінок із непліддям / Г. М. Чорненька, Ю.І.Кузик // Актуальні питання педіатрії, акушерства та гінекології. - 2018. - № 3. C. 94-99.

14. Проблема тонкого эндометрия и возможные пути ее решения / И. В. Кузнецова, Н. С. Землина, Т. Н. Рашидов, М. А. Коваленко // Эффективная фармакотерапия. -2015 . - № 1. - С. 15-25.

15. Спринджук М. В. Ангиогенез / М. В. Спринджук // Морфологія. -2010. - T. IV, № 2. - С. 4-13.

\section{REFERENCES}

1. Indraccolo, U., Di lorio, R., \& Matteo, M. (2013). The pathogenesis of endometrial polyps: a systematic semiquantitative revive. European Journal of Gynaecological Oncology, XXXIV (1), 5-22.

2. Klynyshkova, T.V., Frolova, N.B., \& Mozgovoy, S.I. (2011). Klinicheskoe znachenye kompleksnoy otsenki retseptornogo statusa endometriya pri endometrialnykh polipakh [The clinical significance of a comprehensive assessment of the endometrial receptor status in endometrial polyps]. Akusherstvo i ginekologiya - Obstetrics and Gynecology, 3, 37-41 [in Russian].

3. Kozyreva, E.V., \& Davydyan, L.Yu. (2015). Rol faktorov rosta v patogeneze besplodiya i nevynashyvaniya beremennosti [The role of growth factors in the pathogenesis of infertility and miscarriage]. Sovremennye problemy nauki i obrazovaniya - Modern Problems of Science and Education, 4 [in Russian].

4. Kuzyk, Yu.I., \& Chornenka, H.M. (2018). Hiperplastychni protsesy endometriia u zhinok iz bezplidnistiu: zistavlennia rezultativ ultrasonohrafichnykh ta patomorfolohichnykh doslidzhen endometriia [Hyperplastic processes of endometrium in women with infertility: repro- 
Огляди літератури, оригінальні дослідження, погляд на проблему, ювілеї

duction of ultrasonographies and pathologic dosimetology]. Zdorovye zhenshchiny - Woman's Health, 7 (133), 129-133 [in Ukrainian].

5. Zakharova, N.B., Durnov, D.A., \& Mykhailov, V.Yu. (2011). Diagnosticheskoye znachenye issledovaniya faktora rosta endoteliya sosudov v syvorotke krovi [The diagnostic value of the study of vascular endothelial growth factor in blood serum]. Fundamentalnye issledovaniya Fundamental Researches, 11, 215-220 [in Russian].

6. Hannan, N.J., Paiva, P., Hannan, N.J., \& Meehan, K.L. (2011). Analysis of fertility-related soluble mediators in human uterine fluid identifies VEGF as a key regulator of embryo implantation. Endocrinology, 152, 4948-4956.

7. Carmeliet, P. (2003). Angiogenesis in health and disease. Nat. Med., 9, 653-660. doi: 10.1038/nm0603-653.

8. Burlev, V.A., Yliasova, N.A., \& Shyshkanova, O.A. (2006). Tsyklicheskiy angiogenez eutopicheskogo endometriya [Cyclic angiogenesis of eutopic endometrium]. Problemy reproduktsyy - Problems of Reproduction, 6, 22-30 [in Russian].

9. Lutsenko, S.V., Kyselev, S.M., \& Feldman, N.B. (2004). Molekulyarnye mekhanizmy angiogeneza v fiziologicheskikh i patologicheskykh protsessakh [Molecular mechanisms of angiogenesis in physiological and pathological processes]. Paltsev, M.A. (Ed.). Vvedenye $v$ molekulyarnuyu meditsynu - Introduction in Molecular Medicine. Moscow: OAO “Meditsyna” [in Russian].
10. Dubyna, M.V. (1999). Vliyanye deksametazona na funktsyonalnye svoystva mikrososudov u krys s limfosarkomoy Plyssa [Effect of dexamethasone on the functional properties of microvessels in rats with Pliss lymphosarcoma]. Vopr. Onkologii - Issues of Oncology, 45, 655-669 [in Russian].

11. Tsaltas, J., Rogers, P. A., Gargett, V.C., \& Healy, D.L. (1998). Excessive angiogenesis: a new theory for endometriosis. Current Obst. Gynaecol., 8, 186-188.

12. Binder, N.K., Evans, J., \& Gardner, D.K. (2014). Endometrial signals improve embryo outcome: functional role of vascular endothelial growth factor isoforms on embryo development and implantation in mice. Hum. Reprod., 29 (10), 2278-2286.

13. Chornenka, H.M., \& Kuzyk, Yu.I. (2018). Polipozna transformatsiia endometriia: osoblyvosti diahnostyky $v$ zhinok iz nepliddiam [Polypositive transformation of endometrium: features of diagnosis in women with infertility]. Aktualni pytannia pediatrii akusherstva ta hinekolohii Actual Issues of Pediatrics of Obstetrics and Gynecology, 3, 94-99 [in Ukrainian].

14. Kuznetsova, I.V., Zemlina, N.S., Rashydov, T.N., \& Kovalenko, M.A. (2015). Problema tonkogo endometriya i vozmozhnye puti ee resheniya [The problem of thin endometrium and possible ways of its solution]. Effektivnaya farmakoterapiya - Effective Pharmacotherapy, 1, 15-25 [in Russian].

15. Spryndzhuk, M.V. (2010). Angyogenez [Angiogenesis]. Morfologiya-Morphology, IV (2), 4-13 [in Russian].

\title{
ОСОБЕННОСТИ РЕМОДЕЛИРОВАНИЯ ИЗВИЛИСТИХ АРТЕРИЙ ЭНДОМЕТРИЯ ПРИ ФОРМИРОВАНИИ СОСУДИСТОГО КОМПОНЕНТА ФИБРОВАСКУЛЯРНОГО ЯДРА ПОЛИПОВ У ЖЕНЩИН РЕПРОДУКТИВНОГО ВОЗРАСТА
}

\author{
ГУВЗ «Тернопольский государственный медицинский университет имени И. Я. Горбачевского \\ МОЗ Украины»
}

PEЗЮМЕ. Вопросам ремоделирования эндометрия и его составляющих в последние годы уделяется все больше внимания. Функциональный слой матки обладает уникальным свойством - физиологическим ангиогенезом, зависящим от гормональной цикличности женского организма. Изменения эндометрия в целом и его сосудистого компонента в частности изучены недостаточно. Требует внимания вопрос ремоделирования извилистых артерий функционального слоя матки при воздействии дополнительных внешних факторов.

Цель - на основании патоморфологического анализа архивных препаратов эндометрия женщин репродуктивного возраста с применением дополнительных гистохимических методик определить структурные особенности сосудистого компонента и фиброваскулярного ядра полипов эндометрия.

Материал и методы. Исследовали 55 биопсийных архивных препаратов эндометрия женщин репродуктивного возраста: 43 препарата полипов эндометрия, 12 - физиологического эндометрия. Проводили стандартное окрашивание гематоксилином и эозином, а также использовали дополнительные гистохимические методы: окрашивание резорцин-фуксином по Харту, пикрофусцином по Ван Гизон и треххромным методом Масона.

Результаты. Среди 43 случаев полипов эндометрия выявлено 15 случаев железистых полипов, 26 железисто-стромальных. Клинически у 33 пациенток диагностировано бесплодие, 10 женщин были фертильными. Для контроля отобраны 12 образцов нормального функционального эндометрия, по шесть случаев в фазах пролиферации и секреции.

Гистохимические методы окрашивания позволили определить особенности строения фиброваскулярного ядра полипов эндометрия - наличие ячеек больших толстостенных сосудов, которые часто располагаются цепочками в виде «дорожки». Установлено, что в состав эндометриальной железы в норме входят клетки эпителия и циркулярно расположенные вокруг них волокнистые элементы соединительной ткани, которые визуализируются при использовании дополнительных гистохимических окрашиваний. Наши исследования показали, что в норме в спиральных артериях отсутствуют волокнистые элементы, а в условиях ремоделирования эндометрия в виде полипозной его трансформации - волокнистые элементы являются обязательным элементом артерий. До- 
Огляди літератури, оригінальні дослідження, погляд на проблему, ювілеї

полнительные внешние факторы (такие, как хроническое воспаление и др.) способствуют прогрессирующей васкуляризации полипов. Последняя проявляется не только фиброваскулярным ядром полипа, но и феноменом капилляризации полипов.

Выводы. Наличие фиброваскулярного ядра в полипах эндометрия является проявлением сосудистого ремоделирования, которое заключается в появлении артерий с эластично-коллагеновым каркасом. Скопления сосудов характерны для фиброваскулярной ножки полипа и, наряду с более выраженным волокнистым характером стромы, могут служить ценным дифференциально-диагностическим признаком, отличающим полип от фоновой ткани эндометрия при его небольших размерах. Описанная васкуляризация является решающей для прогрессирующего роста полипа и его возможной малигнизации. Применение дополнительных гистохимических методов позволяет облегчить дифференциальную диагностику полипа как от различных видов гиперплазии, так и нормального эндометрия.

КЛЮЧЕВЫЕ СЛОВА: ремоделирование эндометрия; ангиогенез; полип эндометрия; фиброваскулярное ядро полипа; извилистые артерии; репродуктивный возраст.

\section{FEATURES OF THE REMODELING OF ENDOMETRIUM TORTUOUS ARTERIES DURING THE FORMATION OF THE VASCULAR COMPONENT OF FIBROVASCULAR NUCLEI ENDOMETRIAL POLYPS IN WOMEN OF REPRODUCTIVE AGE}

๑G. M. Chornenka

\section{Horbachevsky Ternopil State Medical University}

SUMMARY. The issues of remodeling of the endometrium and its components in recent years have received increasing attention. The functional layer of the uterus has a unique property - physiological angiogenesis, depending on the hormonal cyclicity of the female body. Changes in the endometrium in general and its vascular component in particular аге not well understood. The issue of remodeling the tortuous arteries of the functional layer of the uterus when exposed to additional external factors requires attention.

The aim of the study - based on the pathological analysis of archival preparations of the endometrium of women of reproductive age using additional histochemical techniques, determine the structural features of the vascular component and the fibrovascular core of endometrial polyps.

Material and Methods. The study included 55 cases of biopsy archival preparations of the endometrium of women of reproductive age: 43 were endometrial polyps, 12 - physiological endometrium. Conducted standard staining with hematoxylin and eosin and additional histochemical methods: resorcin-fuscin by Hart, picrofuscin by Van Gieson and three chrome Masson.

Results and Discussion. Among 43 cases of endometrial polyps, 15 cases of glandular polyps were revealed, 26 cases of glandular-stromal ones. Clinically, 33 patients were diagnosed with infertility, 10 fertile women. For control, 12 samples of normal functional endometrium were selected: in the proliferation phase - six cases and secretion - six.

Histochemical staining methods made it possible to determine the structural features of the fibrovascular nucleus of endometrial polyps - cells of large thick-walled vessels, often arranged in chains in the form of a "track". It is established that the composition of the endometrium of the gland normally includes epithelial cells and fibrous elements of the connective tissue located circularly around them, which are visualized by using additional histochemical staining. Our studies have shown that in the normal spiral arteries there are nofibrous elements, and in the conditions of endometrial remodeling in the form of polypous transformation, fibrous elements are an essential element of the arteries. Additional external factors (such as chronic inflammation, etc.) contribute to the progressive vascularization of polyps. The latter is manifested not only by the fibrovascular nucleus of the polyp, but also by the phenomenon of capillary polyps.

Conclusions. The presence of fibrovascular nuclei in endometrial polyps is a manifestation of vascular remodeling, which consists in the appearance of arteries with an elastically collagen skeleton. Vascular accumulation is characteristic of the fibrovascular nuclei of a polyp and, along with the more pronounced fibrous character of the stroma, can serve as a valuable differential diagnostic sign that distinguishes the polyp from the background tissue of the endometrium with its small size. The described vascularization is crucial for the progressive growth of the polyp and its possible malignancy. The use of additional histochemical methods allows to facilitate the differential diagnosis of a polyp from both different types of hyperplasia and normal endometrium.

KEY WORDS: endometrial remodeling; angiogenesis; endometrial polyp; fibrovascular polyp core; tortuous arteries; reproductive age.

Отримано 28.01.2018 